Fiss, C. J., D. J. McNeil, A. D. Rodewald, D. Heggenstaller, and J. L. Larkin. 2021. Cross-scale habitat selection reveals within-stand structural requirements for fledgling Golden-winged Warblers. Avian Conservation and Ecology 16(1):16. https://doi.org/10.5751/ACE-01807-160116 Copyright (C) 2021 by the author(s). Published here under license by the Resilience Alliance.

Research Paper

\title{
Cross-scale habitat selection reveals within-stand structural requirements for fledgling Golden-winged Warblers
}

\author{
Cameron J. Fiss ${ }^{1,2}$, Darin J. McNeil ${ }^{3,4}$, Amanda D. Rodewald ${ }^{3,5}$, Daniel Heggenstaller ${ }^{6}$ and Jeffery L. Larkin $^{1,7}$ \\ ${ }^{1}$ Indiana University of Pennsylvania, Indiana, PA, USA, ${ }^{2}$ State University of New York, College of Environmental Science and \\ Forestry, Syracuse, NY, USA, ${ }^{3}$ Cornell University, Ithaca, NY, USA, ${ }^{4}$ Pennsylvania State University, State College, PA, USA, \\ ${ }^{5}$ Cornell Lab of Ornithology, Ithaca, NY, USA, ${ }^{6}$ Pennsylvania Game Commission, Jersey Shore, PA, USA, ${ }^{7}$ American Bird \\ Conservancy, The Plains, VA, USA
}

\begin{abstract}
The post-fledging period remains one of the most understudied portions of the avian lifecycle despite the fact that fledglings require resources distinct from those used during nesting. Post-fledging research can further inform breeding grounds management actions and improve conservation outcomes. While the Golden-winged Warbler (Vermivora chrysoptera) is known to make stand-level habitat shifts between nesting and post-fledging, the microhabitat conditions selected by fledglings remains unknown. We used cross-scale habitat selection analyses to evaluate the stand-specific microhabitat conditions required by fledgling Golden-winged Warblers in Pennsylvania. From 2014 through 2017 we radio-tagged and tracked 98 fledglings associated with 80 different sub-broods. We documented habitat use and compared habitat between fledgling and nest sites. Fledglings selected areas with dense overhead and lateral vegetation across stand types. Rubus cover and stem density of $>2 \mathrm{~m}$ saplings were important in stand initiation and stemexclusion stage stands, respectively. In mature forest upland and forested wetlands, fledgling Golden-winged Warblers selected for patches with lower basal area relative to what was available. Compared to nest sites fledgling locations contained less herbaceous cover and greater overhead vegetation density apparently provided by taller woody vegetation. Our findings suggest that management actions have high potential for creating post-fledging Golden-winged Warbler habitat, especially if factors such as invasive species and overbrowsing are controlled during the regeneration stage of stands. Managers may need to take a proactive approach to create the structure required by fledglings in mature forest stand types where largely intact canopies inhibit understory regeneration. Existing management guidelines for the species should be updated to account for the unique vegetation structure required by fledglings during this stage of the lifecycle.
\end{abstract}

\section{La sélection d'habitat à différentes échelles révèle des exigences structurelles intra-peuplements chez les jeunes Parulines à ailes dorées ayant atteint l'âge de l'envol}

RÉSUMÉ. La période qui suit l'envol des jeunes reste l'un des stades les moins étudiés du cycle de vie des oiseaux, malgré le fait que les jeunes ont besoin de ressources différentes de celles utilisées pendant la nidification. La recherche ciblant la période après l'envol des jeunes peut éclairer davantage les activités d'aménagement des lieux de nidification et améliorer les résultats de conservation. Bien que l'on sache que la Paruline à ailes dorées (Vermivora chrysoptera) change de type de peuplements entre la nidification et l'envol, les attributs de microhabitat sélectionnés par les jeunes restent inconnus. Au moyen d'analyses de sélection d'habitat à différentes échelles, nous avons déterminé les attributs de microhabitat spécifiques au peuplement requis par les Parulines à ailes dorées ayant atteint l'âge d'envol en Pennsylvanie. De 2014 à 2017, nous avons marqué à l'aide de radios et suivi 98 jeunes associés à 80 nichées différentes. Nous avons documenté l'utilisation de l'habitat et comparé l'habitat entre les sites utilisés par les jeunes ayant pris leur envol et les sites de nidification. Les jeunes ont choisi des secteurs avec une végétation supérieure et latérale denses dans tous les types de peuplements. La couverture de Rubus et la densité de tiges de gaules de $>2$ m étaient importantes dans les peuplements en phase d'établissement et ceux en phase d'exclusion des arbres, respectivement. Dans les forêts matures poussant en terrain sec et les milieux humides boisés, les jeunes parulines ont choisi des îlots à surface basale plus faible par rapport à ce qui était disponible. Comparativement aux sites de nidification, les sites utilisés par les jeunes comportaient une couverture herbacée plus faible et une densité de végétation supérieure plus grande, apparemment attribuable à une végétation ligneuse plus haute. Nos résultats indiquent que les activités d'aménagement ont un fort potentiel pour créer de l'habitat pour les jeunes Parulines à ailes dorées après leur envol, en particulier si des facteurs tels que les espèces invasives et le broutage excessif sont contrôlés pendant la phase de régénération des peuplements. Les gestionnaires devront peut-être adopter une approche proactive pour créer la structure nécessaire aux jeunes dans les types de peuplements forestiers matures où la voûte largement intacte empêche la régénération du sous-étage. Les directives d'aménagement existantes pour l'espèce devraient être mises à jour pour tenir compte de la structure végétale unique requise par les jeunes durant ce stade de leur cycle de vie.

Key Words: forest management; post-fledging; radio-telemetry; songbird; Vermivora chrysoptera 


\section{INTRODUCTION}

Eastern North American forests face numerous threats including fragmentation (Wade et al. 2003), over-browsing by ungulates (Parker et al. 2020), invasive species (Aronson and Handel 2011), and altered disturbance regimes resulting in homogenous age structure (Shifley et al. 2014), among others (Dietzman et al. 2011). Given the multitude of factors that impact forest ecosystems, it is unsurprising that forest birds have undergone significant population declines over the past half century, culminating in a $\sim 20 \%$ decrease in the population size of this guild (Ford et al. 2009, Rosenberg et al. 2019). A pertinent example of the link between forest health and forest-dependent bird populations is the widespread population declines among shrubland birds attributed to the lack of forest in the stand initiation (i.e., early-successional) stage (Degraaf and Yamasaki 2003, King and Schlossberg 2014). However, for some species, the factors regulating populations remain unclear due to the complex lifecycles of many migratory birds (Rappole and McDonald 1994, Sherry and Holmes 1996). For instance, Wood Thrush (Hylocichla mustelina) population declines may be attributed to both reduced survival during migration (Rushing et al. 2017) or wintering (Taylor et al. 2016) and these effects can be population-specific (Rushing et al. 2016). Given the complex life histories of migratory songbirds, researchers have increasingly called for conservation actions that consider all aspects of the annual lifecycle (Faaborg et al. 2010, Marra et al. 2015).

On the breeding grounds alone, several distinct periods (e.g., settlement, courting, nesting, post-fledging) occur in which birds can exhibit unique behaviors and/or habitat associations (Vitz and Rodewald 2011). However, breeding ground studies have historically focused on nesting or territorial adults given the difficulties associated with relocating fledglings and nonterritorial birds during post-breeding (White and Faaborg 2008, Cox et al. 2014). While the post-fledging period is a relatively short component of the full-annual-cycle, lasting up to two months between fledging and juvenile independence, it has been identified as a critical time period wherein young learn to forage and often disperse before becoming independent (Pagen et al. 2000, Chandler et al. 2012). Additionally, this period has been identified as a potential "population bottleneck" in that it can limit reproductive output and alter demographics (Robinson et al. 2004, Sillet and Holmes 2002, Naef-daenzer and Gruebler 2016, Jones et al. 2020). The availability of high-quality habitat during the post-fledging period has the potential to mitigate challenges faced by fledgling songbirds by improving food availability and providing protective cover (Yackel Adams et al. 2006, Fisher and Davis 2011). As such, studies that identify important vegetation features associated with the post-fledging period can provide insight to guide management actions (i.e., King et al. 2006, Raybuck et al 2020).

Post-fledging songbird studies frequently examine habitat selection, with the assumption that preferred (i.e., selected) habitats are of higher quality (Jones 2001, Johnson 2007). Such studies have laid the groundwork for much of what we know about post-fledging habitat associations for passerine species (Anders et al. 1998, Goguen 2019, Fiss et al. 2020, Raybuck et al. 2020). Habitat selection is also understood to be hierarchical and scale dependent (Johnson et al. 1980), and the choices made at one scale can influence those made at other scales (Francis et al. 2017).
Therefore, it is important to consider how selection patterns interact across spatial scales (e.g., how microhabitat selection is influenced by stand-level selection) because this could dictate management actions at one or both scales. For species known to make stand-level habitat shifts during post-fledging (e.g., Wood Thrush, Anders et al. 1998; Ovenbird [Seiurus aurocapilla], Streby and Andersen 2013; Golden-winged Warbler [Vermivora chrysoptera], Fiss et al. 2020), it would benefit land managers to understand what structural features fledglings use or select and if these preferences are specific to the developmental stage of the stand.

The Golden-winged Warbler is a neotropical migratory passerine that breeds throughout forests of the Appalachians and portions of the western Great Lakes region in North America (Confer et al. 2011). The species builds ground nests in early-successional forest stands or shrub wetlands (McNeil et al. 2014). Mean clutch size for the species is 5 (Confer et al. 2011), though a range of 3 to 6 is not uncommon (C. Fiss personal observation). Broodsplitting occurs after fledgling (Peterson et al. 2016) and fledglings may travel up to $2 \mathrm{~km}$ from nest sites before independence (approximately 28 days post-fledging; Fiss et al. 2020). The species has undergone at least $50 \mathrm{yrs}$ of population declines at rates of $-8.56 \% / y r$ (Appalachians) and $-0.89 \% / y r$ (Great Lakes; Sauer et al. 2017). The Golden-winged Warbler has increasingly become the focus of conservation efforts aimed at stemming these population declines (Rosenberg et al. 2016, McNeil et al. 2020). These efforts largely focused on understanding the habitat factors affecting nest success, forming the basis of best management practices (BMPs) for the species (Bakermans et al. 2011, Roth et al. 2012). The Golden-winged Warbler BMPs have since been extensively implemented on public and private lands (Lutter et al. 2019, McNeil et al. 2020). However, the BMPs focus on nesting habitat could overlook important habitat needs during the postfledging period (Rohrbaugh et al. 2016). Recently, post-fledging habitat selection of Golden-winged Warblers has been studied in the Great Lakes region (Streby et al. 2016, Peterson et al. 2016) and the Appalachians (Lehman 2017, McNeil 2019, Fiss et al. 2020). However, none of these studies investigated fledgling selection for within-stand vegetation features, or how selection preferences may change across different stand developmental stages. To improve the Golden-winged Warbler BMPs, we initiated a multi-year study in 2014 aimed at 1) describing the microhabitat characteristics used and selected by fledgling Golden-winged Warblers within different stand developmental stages and 2) determine differences between fledgling microhabitat and nest habitat.

\section{METHODS}

\section{Study area}

From 2014-2015, we collected data in the Pocono Mountains (Pike and Monroe Counties) of northeastern Pennsylvania (hereafter NE PA) where Golden-winged Warblers historically occur at their highest population densities within the state (Larkin and Bakermans 2012, McNeil et al. 2020). From 2016-2017, we collected data in Centre and Clinton counties in northcentral Pennsylvania (hereafter NC PA). Forests in both study areas (Fig. 1) are characterized by the broadleaf dry oak-heath community (Fike 1999) where stands are dominated by an overstory of oak 
(Quercus spp.) with other hardwood species interspersed (e.g., red maple, Acer rubrum) and an ericaceous understory. These forests are overwhelmingly second-growth with relatively long harvest rotations (80-100 year; Nowacki and Abrams 1992). The primary difference between the NE PA and NC PA study areas was the abundance of wetlands in NE PA and the absence/rarity of similar wetlands in NC PA. Shrub and sapling species composition varied in early-successional stands between the NE PA and NC PA; however, all stands contained blackberry (Rubus spp.) thickets, sedges (e.g., Carex pennsylvanica), and broadleaf herbaceous vegetation like goldenrods (Solidago spp., Euthamia spp.), whorled loosestrife (Lysimachia quadrifolia), and ferns (e.g., Pteridium aquilinum, Dennstaedtia punctilobula).

Fig. 1. A map of Pennsylvania indicating the locations of our two study areas. Fledgling Golden-winged Warblers were studied in the Northeast region (NE PA) during 2014 and 2015 breeding seasons and in the Northcentral region (NC PA) during the 2016 and 2017 breeding seasons.

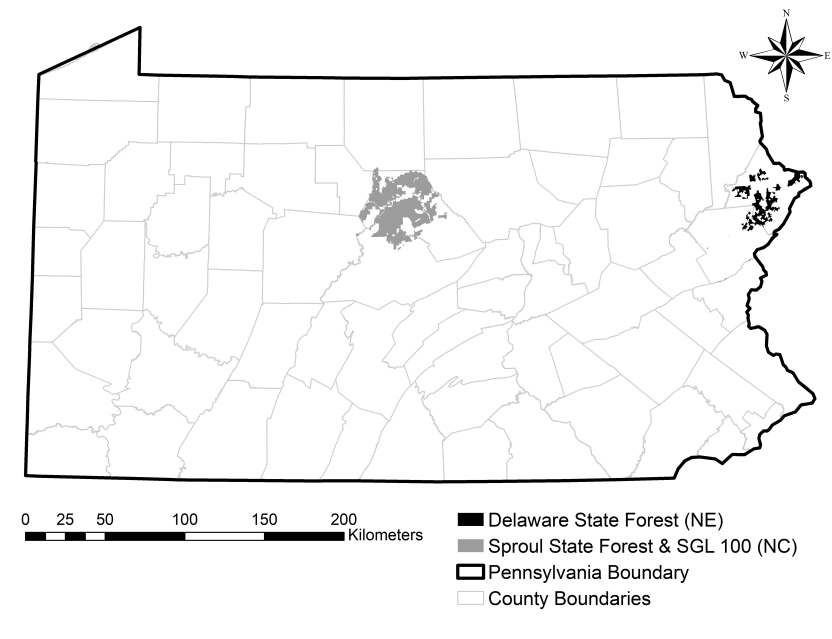

Our NE PA study area encompassed a $\sim 20 \mathrm{~km}$ radius in the Delaware State Forest. Dominant land cover within this study area included broad-leaved forest (75\%), emergent wetlands ( $8 \%$ ), and low-intensity developed land (12\%; Homer et al. 2015). Elevation ranged from 300 to $600 \mathrm{~m}$ above sea level. We studied fledglings from six discrete nesting habitat sites, all of which were the result of recent (2-12 years post-harvest) timber harvests ranging in size from 7 to 63 ha. These regenerating timber stands were comprised of a variety of saplings species including oaks, red maple, aspen (Populus spp.), black cherry (Prunus serotina), black birch (Betula lenta), hickories and occasional pines (Pinus rigida, $P$. strobus). These stands also had well-established shrub layers dominated by scrub oak ( $Q$. ilicifolia), lowbush blueberry (Vaccinium angustifolium), and hillside blueberry (V. pallidum). Understory communities in mature forests were distinct between forested wetlands and upland sites with forested wetlands often hosting great rhododendron (Rhododendron maximum) and highbush blueberry ( $V$. corymbosum) thickets while uplands supported species like scrub oak, witch hazel (Hamemelis virginiana), and mountain laurel (Kalmia latifolia).

Our NC PA study area encompassed a $\sim 30 \mathrm{~km}$ radius in southwest Sproul State Forest and the adjacent State Game Lands 100. Land cover within NC PA included broad-leaved forest $(87 \%)$, agriculture/grasslands (6\%), and low-intensity developed (5\%). Elevation ranged from 500 to $610 \mathrm{~m}$ above sea level. We studied fledglings from 11 early-successional nesting habitat sites (18-96 ha) within NC PA, of which 10 were the result of overstory removal (2-10 years post-harvest) and one was the result of a wildfire that occurred in 1990. In these early-successional stands, a variety of saplings were present including oaks, red maple, aspen, black cherry, pin cherry ( $P$. pennsylvanica), black birch, and pines; however, the shrub component was sparse and consisted mostly of black huckleberry (Gaylusaccia baccata), lowbush blueberry and sweet fern (Comptonia peregrina). Within surrounding mature forest in the NC PA, understory shrubs typically included mountain laurel and occasionally witch hazel.

\section{Data collection}

We searched for Golden-winged Warbler nests from May-June within early-successional forests and along edges of adjacent mature forest across both study areas. We used active searching techniques (e.g., parental behavior cues) to locate nests. For each nest discovered, we conducted checks on a three-day interval to monitor progress and to ensure accurate estimates of nestling age (Martin and Geupel 1993). As nestlings approached fledging (eight days old; Confer et al. 2011), we monitored nests daily.

Immature Golden-winged Warblers were usually marked as nestlings eight days after hatching. However, individuals that fledged prior to nest checks on day eight were caught by hand, typically within $10 \mathrm{~m}$ of the nest. We randomly selected two members of each brood to be fitted with a VHF radio-transmitter (Blackburn Transmitters Inc., Nacogdoches, TX) with $95 \mathrm{~mm}$ antenna. Two fledglings were chosen because parents split broods shortly after fledging (Peterson et al. 2016), and we wanted to increase the chance of monitoring separate sub-broods. Both birds received an aluminum USGS leg band and a radiotransmitter affixed using the figure-eight harness method (Rappole and Tipton 1991). We constructed harnesses from $<1$ mm black elastic thread to allow for growth (Streby et al. 2015). VHF radio-transmitters used in this study weighed either $0.35 \mathrm{~g}$ or $0.40 \mathrm{~g}$, and when combined with a harness and leg band, constituted $<5 \%$ of each bird's mass. There was no obvious indication that transmitters affected mobility or survival of fledglings, and radio-tagged individuals were often seen behaving in a similar fashion to brood-mates without radio-transmitters. However, we do recognize that transmitters may have a small negative effect on survival (Cox et al. 2014). Handling time for each brood was $\leq 10 \mathrm{~min}$ and, upon completion of radio-tagging and banding, all birds were returned to their nest (nestlings) or perch (recently fledged young). In addition to fledglings from monitored nests, we opportunistically captured a small number of dependent fledglings that we encountered during nest searching and telemetry $(\mathrm{N}=14)$. We aged these birds to the nearest day by comparing their plumage characteristics to knownage fledglings (McNeil 2019)

Each of the 98 radio-tagged fledglings was tracked daily between 06:00 and 16:00 using a Lotek STR 1000 (Lotek Wireless Inc., Newmarket, ON) receiver and Yagi three-element antenna. We tracked each fledgling once per day using the homing technique until we visually confirmed its location. Upon arriving at a fledgling's location, we recorded the presence and behaviors of siblings and parents to determine fledgling independence. We 
recorded coordinates at the first location the fledgling was observed using a Garmin eTrex 20 GPS unit (Garmin Intl. Inc., Olathe, KS). We followed this tracking protocol until fledgling mortality $(\mathrm{N}=28)$, radio-transmitter battery failure $(\sim 30$ days; $\mathrm{N}=69$ ), or in one instance, harness failure. When radio signal was lost for an individual, we conducted systematic searches to determine if the fledgling had moved outside the normal detection range of our equipment. Searches were centered on the fledgling's last known location and extended along $1 \mathrm{~km}$ transects in each cardinal direction. If a fledgling remained undetected, we conducted daily searches from an automobile throughout the study area for $\geq 1$ week before ceasing searches $(\mathrm{N}=3)$.

\section{Cover type classification}

We classified cover types in both study areas with ArcGIS 10.3 (Environmental Systems Research, Redlands CA) using a combination of Pennsylvania State Forest and State Game Lands forest inventory data, ArcGIS online aerial imagery (ESRI 2015), National Wetlands Inventory data, and records of recent $(<10$ years) timber harvests on public lands in PA. We classified most cover types based on tree size, stocking level (i.e., tree density relative to the stand's capacity), and age class of the timber stand as described in the PA Department of Conservation and Natural Resources (DCNR) Bureau of Forestry Inventory Manual (PA DCNR 2016). We classified Stand Initiation cover as stands that had recently (approximately $<10$ years) undergone overstory removal harvest and were $>50 \%$ stocked by trees $<15 \mathrm{~cm} \mathrm{DBH}$. Stand initiation (i.e., Golden-winged Warbler nesting habitat) contained substantial shrub and herbaceous ground cover in addition to a diverse mixture of regenerating seedlings/saplings. We defined Stem-exclusion cover as older (approximately 10-25 years post-harvest) even-aged stands $>50 \%$ stocked by trees $<15$ $\mathrm{cm}$ DBH. Stem-exclusion stands were distinct from stand initiation cover due to the dominance of a dense sapling layer such that herbaceous vegetation and most shrubs were shaded out by the overstory. Forested Wetland (NE PA only) and Mature Upland were stands in the understory reinitiation stage. These were characterized by the dominance of trees $>15 \mathrm{~cm} \mathrm{DBH}$ and $>50 \%$ stocking. Forested wetlands were distinct from mature uplands in that they were seasonally or perpetually inundated with water.

\section{Vegetation sampling}

We measured a suite of vegetation variables at i) every fledgling location, ii) at paired available locations, and iii) at nest sites. Paired available points were determined individually based on daily fledgling movement. Briefly, we calculated the straight-line distance from the previous day to the current day for each fledgling. We then used this distance to place a point in a randomly selected direction from the previous day's used location. This methodology, in which availability was determined daily, and on an individual basis, accounts for movement capabilities related to fledgling age and variability in individual condition, which are known to affect movement capabilities of fledgling songbirds (Vitz and Rodewald 2011, Cox et al. 2014). Vegetation surveys for fledgling locations were conducted after fledglings moved $>25 \mathrm{~m}$ away from the area, or we returned the following day to conduct the survey. For logistic reasons, we plotted all available locations for each bird in ArcGIS 10.3 and conducted these vegetation surveys within three weeks after the conclusion of radio-tracking for that year.
At each sampling location, we recorded basal area of stems $>10$ $\mathrm{cm}$ DBH and overhead density (\%) using a 10 -factor cruising prism and a spherical densiometer held at a height of $1.5 \mathrm{~m}$, respectively. We recorded estimates of percent ground cover by herbaceous vegetation or Rubus within a $1 \mathrm{~m}$ radius of plot center. Within a $5 \mathrm{~m}$ radius, we quantified lateral vegetation density using a modified profile board method (Nudds 1977). Our profile board consisted of a fabric sheet containing twenty $20 \times 20 \mathrm{~cm}$ squares. The board was held at plot center allowing an observer to record the number of squares $>50 \%$ visually obstructed by vegetation from a distance of $5 \mathrm{~m}$. The board was rotated $90^{\circ}$ in all four cardinal directions (N, E, S, W) and the observer's line of sight was positioned $1 \mathrm{~m}$ off the ground. We recorded presence of different woody regeneration strata (small, medium, large; fledgling used and available points only) within $1 \mathrm{~m}$ circles at each location the density board was read $(5 \mathrm{~m}$ from plot center in each cardinal direction) to account for heterogeneity in vegetation structure. Small regeneration included any woody stems $<1 \mathrm{~m}$ tall, medium regeneration included any woody stems $>1 \mathrm{~m}$ and $<2 \mathrm{~m}$ tall, and large regeneration included any woody stems that were $>2 \mathrm{~m}$ tall, but $<10 \mathrm{~cm} \mathrm{DBH}$. We estimated average sapling $(<10$ $\mathrm{cm} \mathrm{DBH}$ ) height to the nearest half meter within $5 \mathrm{~m}$ of plot center (Table 1).

Table 1. Description of eight microhabitat variables used in models of cross-scale habitat selection by fledgling Goldenwinged Warblers and for comparing nest sites to locations used by fledglings.

\begin{tabular}{|c|c|}
\hline Variable Name & Description \\
\hline Basal Area & Area $\left(\mathrm{m}^{2} / \mathrm{ha}\right)$ of tree stems $>10 \mathrm{~cm} \mathrm{DBH}$ \\
\hline Lateral Vegetation & $\%$ cover of all vegetation obscuring a $2 \mathrm{~m}$ high \\
\hline Density & profile board \\
\hline Overhead Vegetation & $\%$ cover of all vegetation over $1.5 \mathrm{~m}$ \\
\hline \multicolumn{2}{|l|}{ Density } \\
\hline Rubus & $\%$ cover of Rubus within $1 \mathrm{~m}$ \\
\hline Herbaceous ${ }^{\dagger}$ & $\%$ cover of herbaceous vegetation within $1 \mathrm{~m}$ \\
\hline Sapling & Average height of saplings within $5 \mathrm{~m}$ \\
\hline Medium Regeneration ${ }^{*}$ & $\begin{array}{l}\% \text { area within } 5 \mathrm{~m} \text { with the presence of woody } \\
\text { stem } 1-2 \mathrm{~m} \text { tall }\end{array}$ \\
\hline Large Regeneration ${ }^{*}$ & $\begin{array}{l}\% \text { area within } 5 \mathrm{~m} \text { with the presence of woody } \\
\text { stem }>2 \mathrm{~m} \text { tall }\end{array}$ \\
\hline \multicolumn{2}{|c|}{${ }^{\dagger}$ Variable used only in nest vs fledgling locations model } \\
\hline & dgling habitat selection models \\
\hline
\end{tabular}

\section{Statistical analyses}

We tested for fledgling microhabitat selection with generalized linear mixed models using the package lme4 in program R (Bates 2010, R Core Team 2015). Specifically, we modeled the ability of structural habitat variables to explain the variation between "used" and "available" fledgling locations. Prior to analyses, we scaled and centered all explanatory variables and verified that none were strongly correlated (i.e., Pearson's Correlation Coefficient $>0.7$ ). Because we occasionally tracked two fledglings within the same sub-brood and individuals within the same subbrood were not spatially independent, sub-brood ID was included as a random effect in all habitat selection models. We evaluated incorporating brood ID as an additional random effect, but this term did not improve models, so it was omitted. We also checked for study area effects by comparing study-area-specific global models. We observed no instances in which fledglings selected in 
opposite directions for a variable and thus, combined both study areas for further analyses. To determine which variables most strongly influenced fledgling habitat selection, we assembled models with all-possible-combinations of our vegetation variables using $\mathrm{R}$ package MuMin (Barton and Barton 2015). While the all-possible-combinations approach has been criticized as exploratory (Burnham and Anderson 2002), we believe it is fitting in this circumstance given our ignorance surrounding the post-fledging period and therefore lack of any a priori hypotheses (Symonds and Moussalli 2011). Given that we were interested in determining how microhabitat selection varied across different stand types, we created separate model sets within all forest stand types which had >100 fledgling relocations (see Fiss et al. 2020). Thus, we compared microhabitat models within stand initiation, stem-exclusion, mature upland, and forested wetland stands. We ranked models according to Akaike's Information Criterion adjusted for small sample size (AICc) and defined all models with likelihood values $\geq 0.125$ as 'supported' (Burnham and Anderson 2002). We performed model averaging on all supported models and graphed variable relationships using model-averaged $\beta$ coefficients.

We used a similar modeling approach to test whether fledgling Golden-winged Warblers used different microhabitat within stand initiation stage forest than adult Golden-winged Warblers used for nesting. We did not include woody regeneration variables as these were not collected at nest sites. We included herbaceous ground cover as a variable in these models given its importance to Golden-winged Warbler nesting habitat (Aldinger et al. 2014, $\mathrm{McNeil}$ et al 2017). Nest models used brood ID as a random effect instead of sub-brood ID to account for the fact that both subbroods came from a single nest location. We assumed variables with $95 \% \beta$ coefficients that did not overlap zero, significantly explained differences between fledgling locations and nests. In addition, we report mean values of habitat variables between nests and fledgling locations across all four stand types.

\section{RESULTS}

\section{Microhabitat selection}

We radio-tracked and collected vegetation data from 98 fledgling Golden-winged Warblers in NE PA $\left(\mathrm{N}_{2014}=22, \mathrm{~N}_{2015}=29\right)$ and NC PA $\left(\mathrm{N}_{2016}=24, \mathrm{~N}_{2017}=23\right)$ associated with 80 unique sub-broods. We relocated fledglings $17.9( \pm 0.99)$ times on average during the dependent post-fledging period (i.e., during days 1-28). Across all sub-broods we measured vegetation features at 1759 fledgling locations and 1759 available locations.

We identified support (i.e., likelihood $\geq 0.125$ ) for multiple habitat selection models within the mature upland (14 supported models), stem-exclusion (19 supported models), and forested wetland (29 supported models) model groups; however, only the global model was supported within the stand initiation model group (Appendix 1). Lateral density and basal area were included in the most supported models across all stand types $(76 \%$ and $73 \%$ of supported models respectively) indicating that these features were strong predictors of fledgling habitat selection. Both Rubus cover and medium regeneration occurred in only $33 \%$ of supported models across all stand types. All other covariates occurred in $34 \%-72 \%$ of supported models. The strength of selection for each variable ranged considerably across stand types and some variables were only selected in certain stand types (Fig. 2). For instance, in stand initiation stands, fledglings selected strongly for increased Rubus cover; supported models indicated that Rubus cover $>80 \%$ was associated with a $>70 \%$ probability of use and Rubus cover $<25 \%$ was associated with $<60 \%$ probability of use. Alternatively, in stem-exclusion stands and forested wetlands, fledgling habitat use was independent of Rubus cover. Fledglings used certain microhabitat variables (e.g., sapling height and large regeneration) in different ways, depending on stand type. For example, fledglings avoided tall saplings in stands in the initiation stage while this feature was preferred in stem-exclusion stands (Fig. 2).

Additionally, we identified a number of variables with consistent selection trends across all stands. Greater lateral vegetation density and overhead vegetation density were associated with higher probability of use across all stand types. Lateral vegetation density of $100 \%$ percent was associated with $>50 \%$ probability of use in all stand types and lateral vegetation density of $0 \%$ was associated with $<40 \%$ probability of use in all stands (Fig. 2). Lower basal area was selected for in all stand types, though this relationship was not significant in stem-exclusion stands (Table 2). This indicates that, regardless of cover type (e.g., stand initiation, mature forest, etc.), fledglings consistently selected locations with fewer trees. Medium regenerating stems (1-2 m tall) had no significant relationship with probability of use in any stand type (Fig. 2, Table 2).

Table 2. Model coefficients ( $\beta$ ) and 95\% confidence intervals for all model groups used to evaluate cross-scale habitat selection by fledgling Golden-winged Warblers and fledgling habitat use compared to nest sites. For succinctness, coefficient estimates are only provided for the model with the lowest AICc score in each group, despite model groups containing $>1$ supported model. There was a total of 78 supported models across all groups.

\begin{tabular}{llrrr}
\hline \hline Model Group & Covariate & $\beta$ & Lower & Upper \\
& & & CI & CI \\
\hline Stand Initiation & Basal Area & -0.158 & -0.259 & -0.058 \\
& Lateral Vegetation Density & 0.242 & 0.129 & 0.354 \\
& Overhead Vegetation Density & 0.621 & 0.499 & 0.742 \\
& Sapling Height & -0.317 & -0.431 & -0.203 \\
& Rubus & 0.343 & 0.230 & 0.457 \\
& Medium Woody Regeneration & 0.168 & 0.059 & 0.277 \\
& Large Woody Regeneration & -0.191 & -0.302 & -0.079 \\
Stem-exclusion & Lateral Vegetation Density & 0.480 & 0.203 & 0.758 \\
& Overhead Vegetation Density & 0.193 & -0.058 & 0.444 \\
& Sapling Height & 0.266 & -0.012 & 0.543 \\
& Large Woody Regeneration & 0.402 & 0.156 & 0.648 \\
Mature Upland & -0.331 & -0.534 & -0.129 \\
& Basal Area & 0.512 & 0.318 & 0.706 \\
& Lateral Vegetation Density & 0.325 & 0.132 & 0.519 \\
& Overhead Vegetation Density & 0.182 & -0.016 & 0.379 \\
& Rubus & -0.450 & -0.749 & -0.150 \\
Forested Wetland & Basal Area & -0.365 & -0.657 & -0.046 \\
Nest vs Fledgling & Basal Area & 1.045 & 0.681 & 1.450 \\
& Overhead Vegetation Density & -0.518 & -0.784 & -0.251 \\
& Herbaceous & & & \\
\hline
\end{tabular}

\section{Nest vs fledgling habitat}

We found support for 15 models discerning Golden-winged Warbler fledgling locations from nest site locations (Appendix 1). Both overhead vegetation density and herbaceous cover occurred in all 15 models indicating these variables were useful in describing 
Fig. 2. Relationships between 7 habitat variables and the probability of use by fledgling Golden-winged Warblers based on model averaged estimates. Models assessed habitat selection at the microhabitat scale within 4 distinct stand types to evaluate within-stand habitat associations across scales.
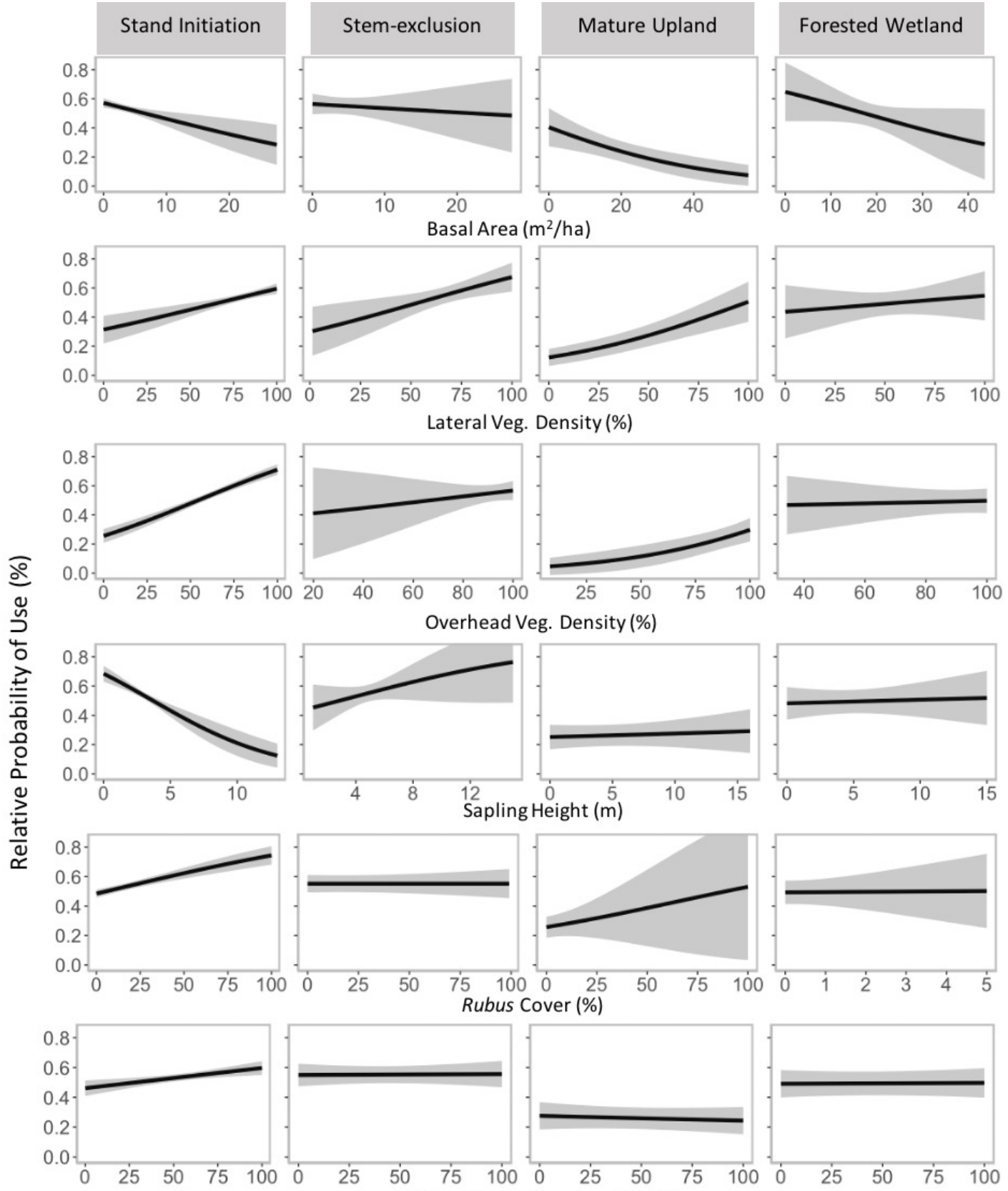

1-2m Woody Regeneration (\%)
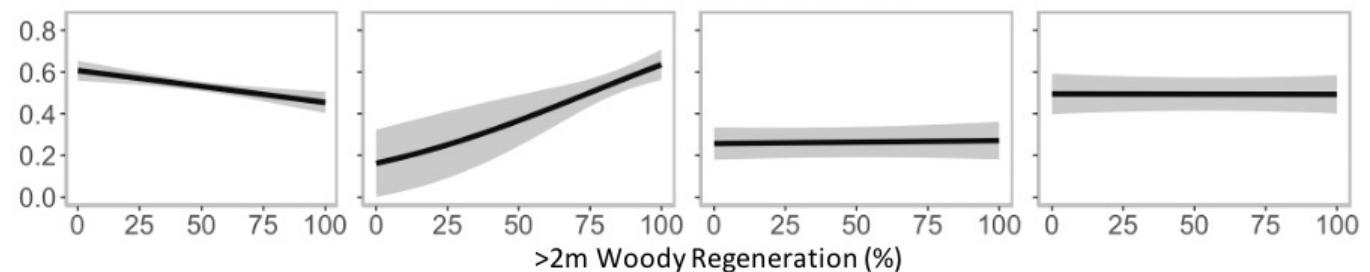
differences in nesting and post-fledging habitat types. In contrast, sapling height and Rubus cover occurred in the fewest models (47\% of models). Two microhabitat variables appeared to significantly influence the difference between post-fledging locations in stand initiation forest and nest locations (Table 2, Fig. $3)$. Fledgling locations were associated with less herbaceous cover $(\beta=-0.52,95 \% \mathrm{CI}=-0.78--0.25)$, and greater overhead vegetation density $(\beta=1.04,95 \% \mathrm{CI}=0.68-1.45)$ than nest sites. Basal area was slightly lower at fledgling locations according to some model estimates (Table 2), though this effect did not seem to be ecologically relevant given similarity in average basal area between nests and fledglings in stand initiation stage stands (Figure 3). Neither lateral vegetation density, Rubus cover, nor sapling height differed between fledgling locations in stand initiation stage forest and nest locations.

Fig. 3. Comparison of vegetation variables at locations used by Golden-winged Warbler fledglings, available locations, and at nest sites, based on the mean value of variables. Error bars represent 95\% confidence intervals. $\mathrm{SI}=$ Stand Initiation, $\mathrm{SE}=$ Stem-exclusion, $\mathrm{MAT}=$ Mature Upland, $\mathrm{FW}=$ Forested Wetland.
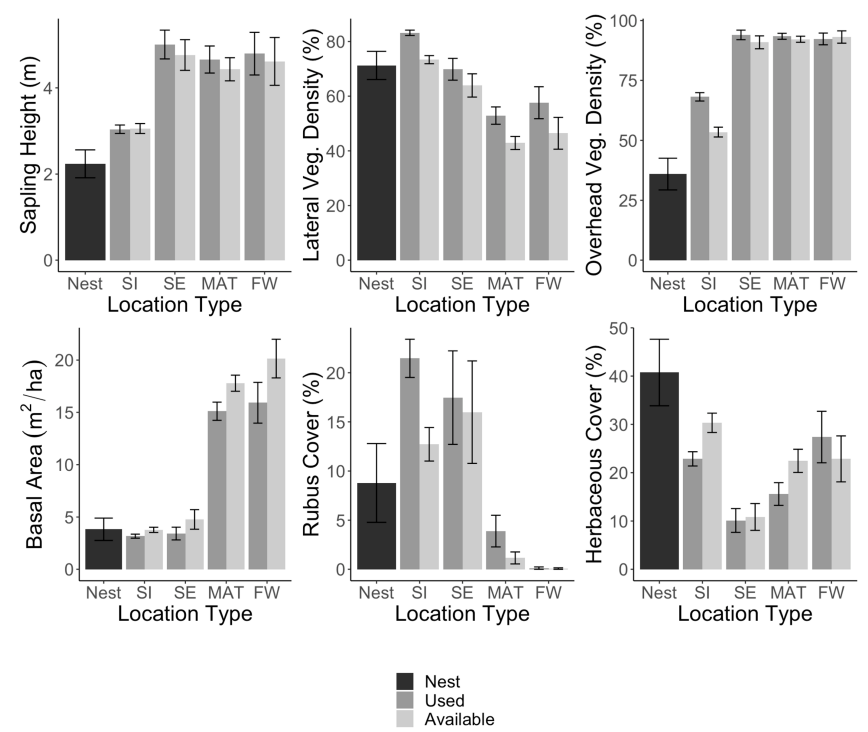

A summary of microhabitat use indicated that use of certain habitat features varied depending on forest stand type, and fledgling microhabitat use differed from nest sites, particularly in stands other than stand initiation (outside of which nests did not occur; Fig. 3). Herbaceous cover at nest sites averaged $>40 \%$; however, fledglings used locations that averaged $<30 \%$ herbaceous cover throughout all stand types. Nest sites averaged sapling height of $\sim 2 \mathrm{~m}$ whereas fledgling locations on average were defined by sapling height $>3 \mathrm{~m}$, particularly in stem-exclusion, mature, and forested wetland stands where sapling heights averaged $>4 \mathrm{~m}$ at fledgling locations (Fig. 3).

\section{DISCUSSION}

Through the use of cross-scale habitat selection models, we demonstrate here that habitat selection patterns for the fledglings of a forest-dependent songbird can vary depending on forest stand type. Because our analyses were stratified by stand type instead of fledgling age, our results can be incorporated readily into forest management plans. Despite some differences across stand types, fledglings consistently selected for greater lateral and overhead vegetation density and lower basal area relative to the available structure in stands, suggesting these features could be limited for fledglings and should be targets for management. In addition, microhabitat features used for nest sites differed strongly from those used by post-fledging broods and these differences became more apparent in stands other than those typically used for nesting (i.e., outside stand initiation stands). While nests were associated with an abundance of herbaceous vegetation, fledglings preferred areas of greater structural complexity provided by taller woody plants (Fig. 4). Our results emphasize the importance of researchers evaluating microhabitat selection and habitat use across spatial scales to better inform management. Additionally, our findings fill a critical knowledge gap in the breeding ecology of Golden-winged Warblers by providing an empirically-derived description of the microhabitat structure required by fledglings during a vulnerable life-stage.

Fig. 4. Examples of microhabitat patches typical of fledgling Golden-winged Warbler habitat in Pennsylvania. A) Forest in the stand initiation stage with patches of more advanced taller regeneration creating greater lateral and overhead vegetation density, B) stem-exclusion stand with high density of $>2 \mathrm{~m}$ tall sapling stems, C) Mature Upland stand exhibiting canopy disturbance and significant understory regeneration.

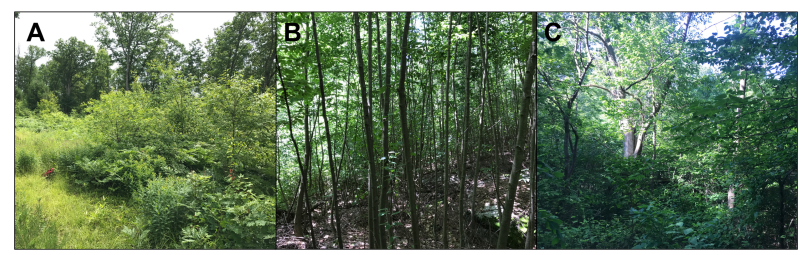

Our findings are consistent with those on fledglings of other species in that we found a strong relationship between probability of use and patches of greater vegetation density. For example, forest birds including Ovenbirds (King et al. 2006, Jenkins et al. 2017), Wood Thrushes (Anders et al. 1998, Lang et al. 2002), Worm-eating Warblers (Helmitheros vermivorum) (Vitz and Rodewald 2011), Acadian Flycatchers (Empidonax virescens) (Jenkins et al. 2017) and Cerulean Warblers (Setophaga cerulea) (Raybuck et al. 2020) have all been associated with areas of dense understory vegetation during the post-fledging period. Our results are most similar to Ovenbirds, Worm-eating Warblers, and Cerulean Warblers, in that fledgling Golden-winged Warblers selected denser vegetation during the dependent post-fledging phase. Alternatively, Wood Thrushes and Acadian Flycatchers primarily selected denser patches after independence from adult care. Previous studies indicate that dense vegetation improves fledgling survival (King et al. 2006, Vitz and Rodewald 2011). However, post-fledging survival studies involving Golden-winged Warblers have not shown a link between daily survival and overhead or lateral vegetation density (Streby et al. 2016, Lehman 
2017, McNeil 2019). Being a species that forages primarily on foliage-dwelling invertebrates (Confer et al. 2011), fledgling Golden-winged Warblers may use denser vegetation because it provides greater foraging potential. Indeed, it has been suggested that insect abundance is greater in dense patches of vegetation, including forest in the stand initiation stage, and this could motivate the use of these habitats during post-fledging (Vitz and Rodewald 2007, Chandler et al. 2012). While overall vegetation density was important, we did not find a relationship between the amount of medium woody regeneration (1-2m woody stems) and probability of habitat use by fledglings. This seems to suggest that selection was more tied to foliage structure, including vines (e.g., Vita spp.) and widely spreading saplings and shrubs (e.g., witch hazel, downy serviceberry [Amalanchier arborea], scrub oak), versus simply the amount of sapling or shrub stems.

Some of the vegetation features that fledgling Golden-winged Warblers selected for in specific stands are inherent to those stand types. For instance, we found that fledgling Golden-winged Warblers selected for areas of more $>2$ m woody stems when using stem-exclusion stands. Dense, tall patches of saplings are inherent to forests in the stem-exclusion stage as a result of natural succession. Similarly, fledglings selected for areas with greater Rubus cover when occupying stand initiation stage forest. Rubus spp. are known to regenerate rapidly in recently clear-cut stands in the Appalachians (Donoso and Nyland 2006). This trend suggests that stand-scale habitat shifts by fledgling Goldenwinged Warblers to stands of different age classes could be driven by the need to use certain microhabitat features within those stands (Fiss et al. 2020). However, one rather counterintuitive cross-scale habitat association we discovered was the selection for patches of lower basal area in mature upland and forested wetland stands. Fledglings in our study used patches in mature uplands that averaged $15 \mathrm{~m}^{2} / \mathrm{ha}( \pm 0.44 \mathrm{SE})$ basal area, which falls below the typical basal area of mature eastern broadleaf forest (19-47 $\mathrm{m}^{2} /$ ha; Keddy and Place 1994). Interestingly, adult male Goldenwinged Warblers make off-territory forays into mature forests with canopy disturbance during the nesting period (Frantz et al. 2016). Our results add support to the idea that these movements could be associated with prospecting for post-fledging habitat. While mature upland stands themselves were not selected for in our study area (though they were used regularly), Golden-winged Warbler fledglings traveled faster when moving through this cover type (Fiss et al. 2020), indicating that mature upland forest may be a low-quality post-fledging habitat type for Appalachian Golden-winged Warblers. With that in mind, patches of lower basal area (often caused by tree mortality) within otherwise mature stands may provide an important micro-refugia comprised of dense overhead and lateral vegetation cover due to advanced understory regeneration.

Our findings that fledglings used areas with less herbaceous cover and greater overhead vegetation density than those used as nest sites, improves our understanding of Golden-winged Warbler breeding habitat requirements. Golden-winged Warbler breeding habitat has historically been defined from the perspective of nests (Buehler et al 2007, Roth et al. 2012, Rohrbaugh et al. 2016). Previous studies have described Golden-winged Warbler nest sites as weedy, herbaceous patches comprised of asters (Aster spp.), goldenrod (Solidago spp.), grasses, and other forbs (Klaus and Buehler 2001, Confer et al. 2011). In fact, some studies reported that adults selected for areas with greater herbaceous cover and fewer saplings in which to place nests (Bulluck and Buehler 2008, Terhune et al. 2016) and nest sites comprised of up to $50 \%$ grass cover can improve daily survival rate of nests (Aldinger et al. 2015). Nests found in our study used similar amounts of herbaceous groundcover $(\sim 40 \%)$; however, fledglings used locations with only $20 \%-25 \%$ herbaceous ground cover. Instead, fledglings used locations with greater overhead vegetation density and taller saplings, suggesting they preferred patches with more advanced woody regeneration than nest sites. These results suggest that management scenarios that create less structural heterogeneity and fail to establish dense patches of taller woody vegetation, such as expansive areas of managed shrublands (e.g., old field management, surface mine reclamation; Degraaf and Yamasaki 2003, Bulluck and Buehler 2006, Leuenberger et al. 2017), could attract nesting Golden-winged Warblers but fail to provide adequate post-fledging habitat. The contrasting needs of nests and fledglings could explain why Golden-winged Warbler territories often include considerable heterogeneity (Confer and Knapp 1981, Rossell et al. 2003), abundant micro-edges (Leuenberger et al. 2017), and why the species utilizes stands that often fail to attain an abundance of areas with optimal nest site characteristics (McNeil et al. 2017). Our findings indicate that adults may choose locations that balance the needs of nests and fledglings in order to improve their overall fitness. Similarly, adult Golden-winged Warblers in the western Great Lakes chose nest locations that either favored nest success or post-fledging survival depending on time of the breeding season Streby et al. (2014).

\section{CONCLUSIONS}

Our study provides evidence that Golden-winged Warblers require a unique set of vegetation features during the postfledging period that are currently not being considered under the species best management practices. While Golden-winged Warblers in our study areas are known to select multiple forest stand developmental stages during the post-fledging period (Fiss et al. 2020), our findings indicate that microhabitat structure within stands could drive this behavior. In particular, patches of dense overhead and lateral vegetation density provided by abundant saplings and shrubs 2-5 $\mathrm{m}$ tall in addition to high Rubus cover are clearly important components within stand initiation forest. Fledglings require similar conditions within stemexclusion stands; however, increased stem density of $>2$ m woody plants is also important. In mature uplands and forested wetlands, fledglings require patches of lower basal area in conjunction with understory regeneration providing lateral and overhead cover. Abundant, spreading shrubs (e.g., witch hazel, downy serviceberry, scrub oak), vines (e.g., Vita spp.), and even taller midstory saplings could help produce these structural conditions. Fortunately, our results suggest that conventional stand scale forest management practices could create the structure required by fledglings. However, managers should mitigate factors that challenge or alter the natural process of regeneration. For instance, over-browsing by white-tailed deer (Odocoileus virginianus) can reduce sapling height and decrease Rubus stem density (Parker et al. 2020), and ground cover monocultures of huckleberry (Gaylussacia spp.), blueberry (Vaccinium spp.), mountain laurel, and hay-scented fern (Dennstaedtia punctilobula) can impede regeneration of native tree species (Avril and Kelty 1999, Fei and Steiner 2008). In landscapes dominated 
Avian Conservation and Ecology 16(1): 16 http://www.ace-eco.org/vol16/iss1/art16/

by forest with largely intact canopies, forest managers should be proactive in creating canopy and understory conditions that meet the needs of Golden-winged Warbler fledglings, especially in areas with high deer densities. One such option is shelterwood harvests, which may be an appropriate way of achieving forest management goals while simultaneously creating habitat for fledgling Golden-winged Warblers. Indeed, basal area in patches used by our fledglings in mature upland forests $\left(15 \mathrm{~m}^{2} / \mathrm{ha}\right)$ is consistent with a first-entry shelterwood harvest in oak systems (Loftis 1983). Such management would overlap with the needs of other declining forest species, such as Cerulean Warbler and Scarlet Tanager (Piranga olivacea) (Wood et al. 2013, Lambert et al. 2017), which breed in mature forest with disturbed canopies. It is important to note, however, these harvests likely will not benefit fledgling Golden-winged Warblers until significant understory regeneration has occurred, a process that could take several years (Miller et al. 2014).

For Golden-winged Warbler conservation actions to be most successful, we recommend that managers be cognizant of spatial positioning of stand improvements and temporal aspects of stand development. In the Appalachians, management done within 2 $\mathrm{km}$ of known Golden-winged Warbler nesting habitat is preferable, given that this falls within the dispersal capabilities of fledglings (Fiss et al. 2020). Within these local landscapes, staggering forest developmental stages through time (e.g., stand initiation, stem-exclusion) such that a mosaic of age classes is present at any given time should provide ample habitat conditions for fledglings. Regenerating patches that are connected by mature forest with healthy, structurally complex understory regeneration may allow fledgling Golden-winged Warblers to travel to locations with preferred vegetation conditions. Given these findings, we recommend that the best management practices for the central Appalachians be reevaluated and updated to address the post-fledging habitat needs of the species.

Responses to this article can be read online at: https://www.ace-eco.org/issues/responses.php/1807

\section{Acknowledgments:}

This material is based upon work supported by the USDA Natural Resources Conservation Service. Any opinions, findings, conclusions, or recommendations expressed in this publication are those of the authors and do not necessarily reflect the views of the USDA. Additional funding was provided by the Pennsylvania Game Commission and the American Bird Conservancy. We thank the Pennsylvania Bureau of Forestry, including Doug D'Amore and Tim Dugan, for access to Sproul State Forest and Delaware State Forest. We thank the Pennsylvania Game Commission for logistical support and access to State Game Lands 100. We thank P. Blackburn for providing high-quality radio-transmitters. We are grateful to the Blooming Grove Hunting and Fishing Club and Easton Anglers Association for access to their lands. Finally, this work would not have been possible without the tireless nest-searching and radio telemetry efforts of our field technicians: $R$. Veasley, F. Rodriguez, K. Rogers, B. Eddinger, D. Hiles, C. Campbell-Schall, J. Geisel, R.
Conner, B. Ramer, N. Christensen, J.T. Larkin, K. Glanville, E. Moser, C. Sayers, and T. Barbee. This study was conducted in accordance with the guidelines of the Institutional Animal Care and Use Committee of Indiana University of Pennsylvania (\#14-1314).

\section{LITERATURE CITED}

Aldinger, K. R., and P. B. Wood. 2014. Reproductive success and habitat characteristics of Golden-winged Warblers in highelevation pasturelands. The Wilson Journal of Ornithology 126:279-287. https://doi.org/10.1676/13-114.1

Aldinger, K. R., T. M. Terhune II, P. B. Wood, D. A. Buehler, M. H. Bakermans, J. L. Confer, D. J. Flaspohler, J. L. Larkin, J. P. Loegering, K. L. Percy, A. M. Roth, and C. G. Smalling. 2015. Variables associated with nest survival of Golden-winged Warblers (Vermivora chrysoptera) among vegetation communities commonly used for nesting. Avian Conservation and Ecology 10 (1):6. https://doi.org/10.5751/ACE-00748-100106

Anders, A. D., J. Faaborg, and F. R. Thompson III. 1998. Postfledging dispersal, habitat use, and home-range size of juvenile Wood Thrushes. The Auk 115:349-358. https://doi. org/10.2307/4089193

Aronson, M. F. and S. N. Handel. 2011. Deer and invasive plant species suppress forest herbaceous communities and canopy tree regeneration. Natural Areas Journal 31:400-407. https://doi. org/10.3375/043.031.0410

Avril, L., and M. J. Kelty. 1999. Establishment and control of hayscented fern: a native invasive species. Biological Invasions 1:223-236. https://doi.org/10.1023/A:1010098316832

Bakermans, M. H., J. L. Larkin, B. W. Smith, T. M. Fearer, and B. C. Jones. 2011. Golden-winged Warbler habitat best management practices for forestlands in Maryland and Pennsylvania. American Bird Conservancy. The Plains, Virginia, USA.

Barton, K., and M. K. Barton. 2015. Package 'MuMIn'. $R$ package version 1:18.

Bates, D., D. Sarkar, M. D. Bates, and L. Matrix. 2007. The lme4 package. $R$ package version 2:74.

Buehler, D. A., A. M. Roth, R. Vallender, T. C. Will, J. L. Confer, R. A. Canterbury, S. B. Swarthout, K. V. Rosenberg, and L. P. Bulluck. 2007. Status and conservation priorities of Goldenwinged Warbler (Vermivora chrysoptera) in North America. The Auk 124:1439-1445. https://doi.org/10.1093/auk/124.4.1439

Bulluck, L. P. and D. A. Buehler. 2006. Avian use of early successional habitats: are regenerating forests, utility right-ofways and reclaimed surface mines the same? Forest Ecology and Management 236:76-84. https://doi.org/10.1016/j.foreco.2006.08.337

Bulluck, L. P., and D. A. Buehler. 2008. Factors influencing Golden-winged Warbler (Vermivora chrysoptera) nest-site selection and nest survival in the Cumberland Mountains of Tennessee. The Auk 125:551-559. https://doi.org/10.1525/ auk.2008.07075 
Burnham, K.P. and D. R. Anderson. 2002. Model selection and multimodel inference: a practical information-theoretic approach. Second edition. Springer-Verlag. New York, New York, USA.

Chandler, C. C., D. I. King, and R. B. Chandler. 2012. Do mature forest birds prefer early-successional habitat during the postfledging period? Forest Ecology and Management 264:1-9. https:// doi.org/10.1016/j.foreco.2011.09.018

Confer, J. L., and K. Knapp.1981. Golden-winged Warblers and Blue-winged Warblers: The relative success of a habitat specialist and a generalist. The Auk 98:108-114.

Confer, J. L., P. Hartman, and A. Roth. 2011. Golden-winged Warbler (Vermivora chrysoptera). In A. Poole, editor. Birds of North America. Number 20. Cornell Laboratory of Ornithology, Ithaca, New York, USA. https://doi.org/10.2173/bow.gowwar.01

Cox, W. A., F. R. Thompson III, A. S. Cox, and J. Faaborg. 2014. Post-fledging survival in passerine birds and the value of postfledging studies to conservation. The Journal of Wildlife Management 78:183-193. https://doi.org/10.1002/jwmg.670

DeGraaf, R. M., and M. Yamasaki. 2003. Options for managing early-successional forest and shrubland bird habitats in the northeastern United States. Forest Ecology and Management 185:179-191. https://doi.org/10.1016/S0378-1127(03)00254-8

Dietzman, D., K. LaJeunesse, S. Wormstead. 2011. Northern Forest Futures Project: scoping of issues in the forests of the Northeast and Midwest of the United States. Version 3.0. U.S. Department of Agriculture, Forest Service, Northern Research Station. Newtown Square, Pennsylvania, USA.

Donoso, P. J., and R. D. Nyland. 2006. Interference to hardwood regeneration in northeastern North America: The effects of raspberries (Rubus spp.) following clearcutting and shelterwood methods. Northern Journal of Applied Forestry 23:288-296. https:// doi.org/10.1093/njaf/23.4.288

Faaborg, J., R. T. Holmes, A. D. Anders, K. L. Bildstein, K. M. Dugger, S. A. Gauthreaux Jr, P. Heglund, K. A. Hobson, A. E. Jahn, D. H. Johnson, and S. C. Latta. 2010. Conserving migratory land birds in the New World: Do we know enough? Ecological applications 20:398-418. https://doi.org/10.1890/09-0397.1

Fei, S., and K. Steiner. 2008. Relationships between advance oak regeneration and biotic and abiotic factors. Tree Physiology 28:1111-1119. https://doi.org/10.1093/treephys/28.7.1111

Fike, J. 1999. Terrestrial \& palustrine plant communities of Pennsylvania. Bureau of Forestry, Pennsylvania Department of Conservation and Natural Resources, Harrisburg, Pennsylvania, USA.

Fisher, R. J. and S. K. Davis. 2011. Post-fledging dispersal, habitat use, and survival of Sprague's pipits: Are planted grasslands a good substitute for native? Biological Conservation 144:263-271. https://doi.org/10.1016/j.biocon.2010.08.024

Fiss, C. J., D. J. McNeil, A. D. Rodewald, J. E. Duchamp, and J. L. Larkin. 2020. Post-fledging Golden-winged Warblers require forests with multiple stand developmental stages. The Condor 12 (4). https://doi.org/10.1093/condor/duaa052
Ford, B., P. Schmidt. and M. Chu. 2009. The State of the Birds United States of America 2009. U.S. Department of Interior: Washington, DC.

Francis, R. A., J. D. Taylor, E. Dibble, B. Strickland, V. M. Petro, C. Easterwood, and G. Wang. 2017. Restricted cross-scale habitat selection by American beavers. Current Zoology 63:703-710. https://doi.org/10.1093/cz/zox059

Frantz, M. W., K. R. Aldinger, P. B. Wood, J. Duchamp, T. Nuttle, A. Vitz, and J. L. Larkin. 2016. Space and habitat use of breeding Golden-winged Warblers in the central Appalachian Mountains. Golden-winged Warbler ecology, conservation, and habitat management. Studies in Avian Biology 49:81-94. https://doi. org/10.1201/9781315372945-14

Goguen, C. B. 2019. Survival, Movements, and Habitat Use of Fledgling Veeries (Catharus fuscescens) in Northeastern Pennsylvania. The American Midland Naturalist 181:18-28. https://doi.org/10.1674/0003-0031-181.1.18

Homer, C., J. Dewitz, L. Yang, S. Jin, P. Danielson, G. Xian, J. Coulston, N. Herold, J. Wickham, and K. Megown. 2015. Completion of the 2011 National Land Cover Database for the conterminous United States-representing a decade of land cover change information. Photogrammetric Engineering \& Remote Sensing 81:345-354.

Horsley, S.B. 1988. How vegetation can influence regeneration. In H. C. Smith, A. W. Perkins, and W. E Kidd, editors. Proceedings: Guidelines for regenerating Appalachian Hardwood Stands. May 24-26. Morgantown, WV. SAF Publication, 88-03, West Virginia University Books, pp 38-55.

Jenkins, J. M., F. R. Thompson III, and J. Faaborg. 2017. Speciesspecific variation in nesting and postfledging resource selection for two forest breeding migrant songbirds. PloS one 12:e0179524. https://doi.org/10.1371/journal.pone.0179524

Johnson, D. H. 1980. The comparison of usage and availability measurements for evaluating resource preference. Ecology 61:65-71. https://doi.org/10.2307/1937156

Johnson, M. D. 2007. Measuring habitat quality: a review. The Condor 109:489-504. https://doi.org/10.1093/condor/109.3.489

Jones, J. 2001. Habitat selection studies in avian ecology: a critical review. The Auk 118:557-562. https://doi.org/10.1093/auk/118.2.557

Jones, T. M., J. D. Brawn, I. J. Ausprey, A. C. Vitz, A. D. Rodewald, D. W. Raybuck, T. J. Boves, C. J. Fiss, D. J. McNeil, S. H. Stoleson, J. L. Larkin, W. A. Cox, A. C. Schwarzer, N. P. Horsley, E. M. Trumbo, and M. P. Ward. 2020. Parental benefits and offspring costs reflect parent-offspring conflict over the age of fledging among songbirds. Proceedings of the National Academy of Sciences 117(48):30539-30546. https://doi.org/10.1073/pnas.2008955117

Keddy, C. and C. Place, 1994. Forest structure in eastern North America. Eastern Ontario Model Forest. Information Report No. 9, Ontario Ministry of Natural Resources. Peterborough, Ontario, Canada.

Klaus, N. A., and D. A. Buehler. 2001. Golden-winged Warbler breeding habitat characteristics and nest success in clearcuts in 
Avian Conservation and Ecology 16(1): 16

the southern Appalachian Mountains. The Wilson Journal of Ornithology 113:297-301.

King, D. I., R. M. Degraaf, M. L. Smith, and J. P. Buonaccorsi. 2006. Habitat selection and habitat-specific survival of fledgling ovenbirds (Seiurus aurocapilla). Journal of Zoology 269:414-421. https://doi.org/10.1111/j.1469-7998.2006.00158.x

King, D. I., and S. Schlossberg. 2014. Synthesis of the conservation value of the early-successional stage in forests of eastern North America. Forest Ecology and Management 324:186-195. https://doi.org/10.1016/j.foreco.2013.12.001

Lambert, J. D., B. Leonardi, G. Winant, C. Harding, and L. Reitsma. 2017. Guidelines for managing wood thrush and scarlet tanager habitat in the Northeast and Mid-Atlantic regions. High Branch Conservation Services, Hartland, Vermont, USA.

Lang, J. D., L. A. Powell, D. G. Krementz, and M. J. Conroy. 2002. Wood Thrush movements and habitat use: effects of forest management for Red-cockaded Woodpeckers. The Auk 119:109-124. https://doi.org/10.1093/auk/119.1.109

Larkin, J. L., and M. H. Bakermans. 2012. Golden-winged Warbler, Vermivora chrysoptera. Second Atlas of Breeding Birds in Pennsylvania. Penn State University Press, State College, Pennsylvania, USA. 350-351. https://doi.org/10.2173/bow. gowwar.01

Lehman, J. A. 2017. Survival and habitat selection of Goldenwinged Warblers (Vermivora chrysoptera) during nesting and postfledging periods at North Cumberland Wildlife Management Area, Tennessee. Thesis, University of Tennessee, Knoxville, Tennessee, USA.

Leuenberger, W., D. J. McNeil, J. Cohen, and J. L. Larkin. 2017. Characteristics of Golden-winged Warbler territories in plant communities associated with regenerating forest and abandoned agricultural fields. Journal of Field Ornithology 88:169-183. https://doi.org/10.1111/jofo.12196

Loftis, D. L.1983. Regenerating southern Appalachian mixed hardwood stands with the shelterwood method. Southern Journal of Applied Forestry 7:212-217. https://doi.org/10.1093/sjaf/7.4.212

Lutter, S. H., A. A. Dayer, A. D. Rodewald, D. J. McNeil, and J. L. Larkin. 2019. Early successional forest management on private lands as a coupled human and natural system. Forests 10:499. https://doi.org/10.3390/f10060499

Marra, P. P., E. B. Cohen, S. R. Loss, J. E. Rutter, and C. M. Tonra. 2015. A call for full annual cycle research in animal ecology. Biology letters 11:20150552. https://doi.org/10.1098/rsbl.2015.0552

Martin, T. E., and G. R. Geupel. 1993. Nest-Monitoring Plots: Methods for Locating Nests and Monitoring Success (Métodos para localizar nidos y monitorear el éxito de estos). Journal of field Ornithology 64:507-519.

McNeil, D. J., K. R. Aldinger, M. H. Bakermans, J. A. Lehman, A. C. Tisdale, J. A. Jones, P. B. Wood, D. A. Buehler, C. G. Smalling, L. Siefferman, and J. L. Larkin, 2017. An evaluation and comparison of conservation guidelines for an at-risk migratory songbird. Global Ecology and Conservation 9:90-103. https://doi.org/10.1016/j.gecco.2016.12.006

McNeil, D. J. 2019. Population Dynamics of Species Recovery: Multiscale Demography in Restored Habitats. Dissertation. Cornell University, Ithaca, New York, USA.

McNeil, D. J., A. D. Rodewald, V. Ruiz-Gutierrez, K. E. Johnson, M. Strimas-Mackey, S. Petzinger, O. J. Robinson, G. E. Soto, A. A. Dhondt, and J. L. Larkin. 2020. Multiscale drivers of restoration outcomes for an imperiled songbird. Restoration Ecology. https://doi.org/10.1111/rec.13147

Miller, G.W., J. N. Kochenderfer, J. D. Kochenderfer, and K. W. Gottschalk. 2014. Ten-year response of competing vegetation after oak shelterwood treatments in West Virginia. In Groninger, John W.; Holzmueller, Eric J.; Nielsen, Clayton K.; Dey, Daniel C., editors. Proceedings, 19th Central Hardwood Forest Conference; 2014 March 10-12; Carbondale, IL. General Technical Report NRS-P-142. Newtown Square, PA: US Department of Agriculture, Forest Service, Northern Research Station: 156-171.

Naef-Daenzer, B., and M. U. Grüebler. 2016. Post-fledging survival of altricial birds: Ecological determinants and adaptation. Journal of Field Ornithology 87:227-250. https://doi. org/10.1111/jofo. 12157

Nowacki, G. J., and M. D. Abrams. 1992. Community, edaphic, and historical analysis of mixed oak forests of the Ridge and Valley Province in central Pennsylvania. Canadian Journal of Forest Research 22:790-800. https://doi.org/10.1139/x92-108

Nudds, T. D. 1977. Quantifying the vegetative structure of wildlife cover. Wildlife Society Bulletin 5:113-117.

Pagen, R. W., F. R. Thompson III, and D. E. Burhans. 2000. Breeding and post-breeding habitat use by forest migrant songbirds in the Missouri Ozarks. The Condor 102:738-747. https://doi.org/10.1093/condor/102.4.738

Parker, H. A., J. T. Larkin, D. Heggenstaller, J. Duchamp, M. C. Tyree, C. S. Rushing, E. J. Domoto, and J. L. Larkin. 2020. Evaluating the impacts of white-tailed deer (Odocoileus virginianus) browsing on vegetation in fenced and unfenced timber harvests. Forest Ecology and Management 473:118326. https://doi.org/10.1016/j.foreco.2020.118326

Peterson, S. M., H. M. Streby, and D. E. Andersen. 2016. Spatially explicit models of full-season productivity and implications for landscape management of Golden-winged Warblers in the western Great Lakes region. Studies in Avian Biology 49:141-161. https://doi.org/10.1201/9781315372945-18

R Core Team. 2015. R: a language and environment for statistical computing. R Foundation for Statistical Computing, Vienna, Austria.

Rappole, J. H., and A. R. Tipton. 1991. New harness design for attachment of radio transmitters to small passerines (Nuevo Diseño de Arnés para Atar Transmisores a Passeriformes Pequeños). Journal of field Ornithology 62:335-337. 
Rappole, J. H., and M. V. McDonald. 1994. Cause and effect in population declines of migratory birds. The Auk 111:652-660.

Raybuck, D. W., J. L. Larkin, S. H. Stoleson, and T. J. Boves. 2020. Radio-tracking reveals insight into survival and dynamic habitat selection of fledgling Cerulean Warblers. The Condor 122:duz063. https://doi.org/10.1093/condor/duz063

Robinson, R. A., R. E. Green, S. R. Baillie, W. J. Peach, and D. L. Thomson. 2004. Demographic mechanisms of the population decline of the song thrush Turdus philomelos in Britain. Journal of Animal Ecology 73:670-682. https://doi.org/10.1111/ j.0021-8790.2004.00841.x

Rohrbaugh, R. W., D. A. Buehler, S. B. Swarthout, D. I. King, J. L. Larkin, K. V. Rosenberg, A. M. Roth, R. Vallender, and T. Will. 2016. Conservation perspectives: review of new science and primary threats to Golden-winged Warblers. Studies in Avian Biology 49:207-215. https://doi.org/10.1201/9781315372945-24

Rosenberg, K. V., A. M. Dokter, P. J. Blancher, J. R. Sauer, A. C. Smith, P. A. Smith, J. C. Stanton, A. Panjabi, L. Helft, M. Parr, and P. P. Marra. 2019. Decline of the North American avifauna. Science 366:120-124. https://doi.org/10.1126/science.aaw1313

Rosenberg, K. V., T. Will, D. A. Buehler, S. B. Swarthout, W. E. Thogmartin, R. E. Bennett, and R. Chandler. 2016. Dynamic distributions and population declines of Golden-winged Warblers: Chapter 1. Studies in Avian Biology 49:3-28.

Rossell Jr, C. R., S. C. Patch, and S. P. Wilds. 2003. Attributes of Golden-winged Warbler territories in a mountain wetland. Wildlife Society Bulletin 31:1099-1104.

Roth, A. M., R. W. Rohrbaugh, T. Will, and D. A. Buehler, editors. 2012. Golden-winged Warbler status review and conservation plan. Golden-winged Warbler Working Group. https:/gwwa.org/wpcontent/uploads/2020/06/GWWA_Conservation-Plan_191007_lowres.pdf

Rushing, C. S., Ryder, T. B., and Marra, P. P. 2016. Quantifying drivers of population dynamics for a migratory bird throughout the annual cycle. Proceedings of the Royal Society B: Biological Sciences 283:20152846. https://doi.org/10.1098/rspb.2015.2846

Rushing, C. S., J. A. Hostetler, T. S. Sillett, P. P. Marra, J. A. Rotenberg, and T. B. Ryder. 2017. Spatial and temporal drivers of avian population dynamics across the annual cycle. Ecology 98:2837-2850. https://doi.org/10.1002/ecy.1967

Sauer, J. R., D. K. Niven, J. E. Hines, D. J. Ziolkowski Jr, K. L. Pardieck, J. E. Fallon, and W. A. Link. 2017. The North American Breeding Bird Survey, Results and Analysis 1966 - 2015. Version 2.07.2017 USGS Patuxent Wildlife Research Center, Laurel, Maryland, USA.

Sherry, T. W., and R. T. Holmes. 1996. Winter habitat quality, population limitation, and conservation of Neotropical-Nearctic migrant birds. Ecology 77:36-48. https://doi.org/10.2307/2265652

Shifley, S. R., W. K. Moser, D. J. Nowak, P. D. Miles, B. J. Butler, F. X. Aguilar, R. D. DeSantis, and E. J. Greenfield. 2014. Five anthropogenic factors that will radically alter forest conditions and management needs in the northern United States. Forest Science 60:914-925. https://doi.org/10.5849/forsci.13-153
Sillett, T. S., and R. T. Holmes. 2002. Variation in survivorship of a migratory songbird throughout its annual cycle. Journal of Animal Ecology 71:296-308. https://doi.org/10.1046/ j.1365-2656.2002.00599.x

Streby, H. M., and D. E. Andersen. 2013. Movements, cover-type selection, and survival of fledgling Ovenbirds in managed deciduous and mixed coniferous-deciduous forests. Forest Ecology and Management 287:9-16. https://doi.org/10.1016/j. foreco.2012.08.046

Streby, H. M., J. M. Refsnider, S. M. Peterson, and D. E. Andersen. 2014. Retirement investment theory explains patterns in songbird nest-site choice. Proceedings of the Royal Society B: Biological Sciences 281:20131834. https://doi.org/10.1098/ rspb.2013.1834

Streby, H. M., T. L. McAllister, S. M. Peterson, G. R. Kramer, J. A. Lehman, and D. E. Andersen. 2015. Minimizing marker mass and handling time when attaching radio-transmitters and geolocators to small songbirds. The Condor: Ornithological Applications 117:249-255. https://doi.org/10.1650/CONDOR-14-182.1

Streby, H. M., S. M. Peterson, and D. E. Andersen. 2016. Survival and habitat use of fledgling Golden-winged Warblers in the western Great Lakes region. Golden-winged Warbler ecology, conservation, and habitat management. Studies in Avian Biology 49:127-140. https://doi.org/10.1201/9781315372945-17

Symonds, M. R., and A. Moussalli. 2011. A brief guide to model selection, multimodel inference and model averaging in behavioural ecology using Akaike's information criterion. Behavioral Ecology and Sociobiology 65:13-21. https://doi. org/10.1007/s00265-010-1037-6

Taylor, C. M., and B. J. Stutchbury. 2016. Effects of breeding versus winter habitat loss and fragmentation on the population dynamics of a migratory songbird. Ecological Applications 26:424-437. https://doi.org/10.1890/14-1410

Terhune II, T. M., K. R. Aldinger, D. A. Buehler, D. J. Flaspohler, J. L. Larkin, J. P. Loegering, K. L. Percy, A. M. Roth, C. G. Smalling, and P. Wood. 2016. Golden-winged Warbler nest-site habitat selection: Chapter 7. Studies in Avian Biology 49:109-125.

Vitz, A. C., and A. D. Rodewald. 2011. Influence of condition and habitat use on survival of post-fledging songbirds. The Condor 113:400-411. https://doi.org/10.1525/cond.2011.100023

Wade, T. G., K. H. Riitters, J. D. Wickham, and K. B. Jones. 2003. Distribution and causes of global forest fragmentation. Conservation Ecology 7(2):7. https://doi.org/10.5751/ES-00530-070207

White, J. D., and J. Faaborg. 2008. Post-fledging movement and spatial habitat-use patterns of juvenile Swainson's Thrushes. The Wilson Journal of Ornithology 120:62-73. https://doi. org/10.1676/06-142.1

Wood, P., J. Sheehan, P. D. Keyser, D. A. Buehler, J. Larkin, A. D. Rodewald, S. H. Stoleson, T. B. Wigley, J. Mizel, T. J. Boves, and G. George. 2013. Management guidelines for enhancing Cerulean Warbler breeding habitat in Appalachian hardwood forests. American Bird Conservancy. The Plains, Virginia, USA. 
Yackel Adams, A. A., S. K. Skagen, and J. A. Savidge. 2006. Modeling post-fledging survival of lark buntings in response to ecological and biological factors. Ecology 87:178-188. https://doi. org/10.1890/04-1922

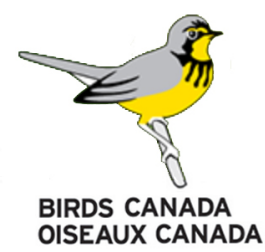




\begin{tabular}{|c|c|c|c|c|c|}
\hline & Model & $\mathrm{K}$ & $\Delta \mathrm{AIC}_{\mathrm{c}}$ & Weight & Likelihood \\
\hline $\begin{array}{l}\text { Stand } \\
\text { Initiation }\end{array}$ & $\begin{array}{l}\text { Basal Area }+ \text { Overhead Density }+ \text { Lateral } \\
\text { Density }+ \text { Rubus }+ \text { Sapling Height }+ \text { Large } \\
\text { Regeneration }+ \text { Medium Regeneration }\end{array}$ & 9 & 0 & 1.00 & 1.000 \\
\hline & Null & 2 & 238.62 & 0.00 & 0.000 \\
\hline \multirow[t]{20}{*}{$\begin{array}{l}\text { Stem- } \\
\text { exclusion }\end{array}$} & $\begin{array}{l}\text { Overhead Density }+ \text { Lateral Density }+ \text { Sapling } \\
\text { Height }+ \text { Large Regeneration }\end{array}$ & 6 & 0 & 0.14 & 1.000 \\
\hline & Lateral Density + Sapling Height + Large Regeneration & 5 & 0.29 & 0.12 & 0.866 \\
\hline & $\begin{array}{l}\text { Basal Area }+ \text { Overhead Density }+ \text { Lateral Density }+ \text { Sapling } \\
\text { Height }+ \text { Large Regeneration }\end{array}$ & 7 & 0.89 & 0.09 & 0.642 \\
\hline & $\begin{array}{l}\text { Basal Area }+ \text { Lateral Density }+ \text { Sapling Height }+ \text { Large } \\
\text { Regeneration }\end{array}$ & 6 & 1.01 & 0.09 & 0.602 \\
\hline & Overhead Density + Lateral Density + Large Regeneration & 5 & 1.54 & 0.07 & 0.464 \\
\hline & $\begin{array}{l}\text { Overhead Density }+ \text { Lateral Density }+ \text { Sapling } \\
\text { Height }+ \text { Large Regeneration }+ \text { Medium Regeneration }\end{array}$ & 7 & 2.03 & 0.05 & 0.362 \\
\hline & $\begin{array}{l}\text { Overhead Density }+ \text { Lateral Density }+ \text { Rubus }+ \text { Sapling } \\
\text { Height }+ \text { Large Regeneration }\end{array}$ & 7 & 2.08 & 0.05 & 0.353 \\
\hline & $\begin{array}{l}\text { Basal Area }+ \text { Overhead Density }+ \text { Lateral Density }+ \text { Large } \\
\text { Regeneration }\end{array}$ & 6 & 2.16 & 0.05 & 0.339 \\
\hline & $\begin{array}{l}\text { Lateral Density }+ \text { Sapling Height }+ \text { Large } \\
\text { Regeneration }+ \text { Medium Regeneration }\end{array}$ & 6 & 2.23 & 0.05 & 0.328 \\
\hline & $\begin{array}{l}\text { Lateral Density }+ \text { Rubus }+ \text { Sapling Height }+ \text { Large } \\
\text { Regeneration }+\end{array}$ & 6 & 2.36 & 0.04 & 0.308 \\
\hline & $\begin{array}{l}\text { Basal Area }+ \text { Overhead Density }+ \text { Lateral Density }+ \text { Sapling } \\
\text { Height }+ \text { Large Regeneration }+ \text { Medium Regeneration }\end{array}$ & 8 & 2.91 & 0.03 & 0.233 \\
\hline & $\begin{array}{l}\text { Basal Area }+ \text { Lateral Density }+ \text { Sapling Height }+ \text { Large } \\
\text { Regeneration }+ \text { Medium Regeneration }\end{array}$ & 7 & 2.94 & 0.03 & 0.230 \\
\hline & $\begin{array}{l}\text { Basal Area }+ \text { Overhead Density }+ \text { Lateral } \\
\text { Density }+ \text { Rubus }+ \text { Sapling Height }+ \text { Large Regeneration }\end{array}$ & 8 & 2.98 & 0.03 & 0.225 \\
\hline & $\begin{array}{l}\text { Basal Area }+ \text { Lateral Density }+ \text { Rubus }+ \text { Sapling } \\
\text { Height }+ \text { Large Regeneration }+\end{array}$ & 7 & 3.02 & 0.03 & 0.221 \\
\hline & $\begin{array}{l}\text { Overhead Density }+ \text { Lateral Density }+ \text { Rubus }+ \text { Large } \\
\text { Regeneration }\end{array}$ & 6 & 3.46 & 0.03 & 0.177 \\
\hline & Lateral Density + Large Regeneration & 4 & 3.51 & 0.03 & 0.173 \\
\hline & $\begin{array}{l}\text { Overhead Density }+ \text { Lateral Density }+ \text { Large } \\
\text { Regeneration }+ \text { Medium Regeneration }\end{array}$ & 6 & 3.56 & 0.02 & 0.169 \\
\hline & Basal Area +Lateral Density +Large Regeneration & 5 & 3.85 & 0.02 & 0.146 \\
\hline & $\begin{array}{l}\text { Overhead Density }+ \text { Lateral Density }+ \text { Rubus }+ \text { Sapling } \\
\text { Height }+ \text { Large Regeneration }+ \text { Medium Regeneration }\end{array}$ & 8 & 4.13 & 0.02 & 0.127 \\
\hline & Null & 2 & 15.53 & 0.00 & 0.000 \\
\hline \multirow{5}{*}{$\begin{array}{l}\text { Mature } \\
\text { Upland }\end{array}$} & & 6 & 0 & 0.18 & 1.000 \\
\hline & Basal Area + Overhead Density + Lateral Density + Rubus & & & & \\
\hline & $\begin{array}{l}\text { Basal Area }+ \text { Overhead Density }+ \text { Lateral } \\
\text { Density }+ \text { Rubus }+ \text { Medium Regeneration }\end{array}$ & 7 & 0.82 & 0.12 & 0.663 \\
\hline & $\begin{array}{l}\text { Basal Area }+ \text { Overhead Density }+ \text { Lateral } \\
\text { Density }+ \text { Rubus }+ \text { Sapling Height }\end{array}$ & 7 & 0.97 & 0.11 & 0.615 \\
\hline & $\begin{array}{l}\text { Basal Area }+ \text { Overhead Density }+ \text { Lateral } \\
\text { Density }+ \text { Rubus }+ \text { Large Regeneration }\end{array}$ & 7 & 1.56 & 0.08 & 0.458 \\
\hline
\end{tabular}




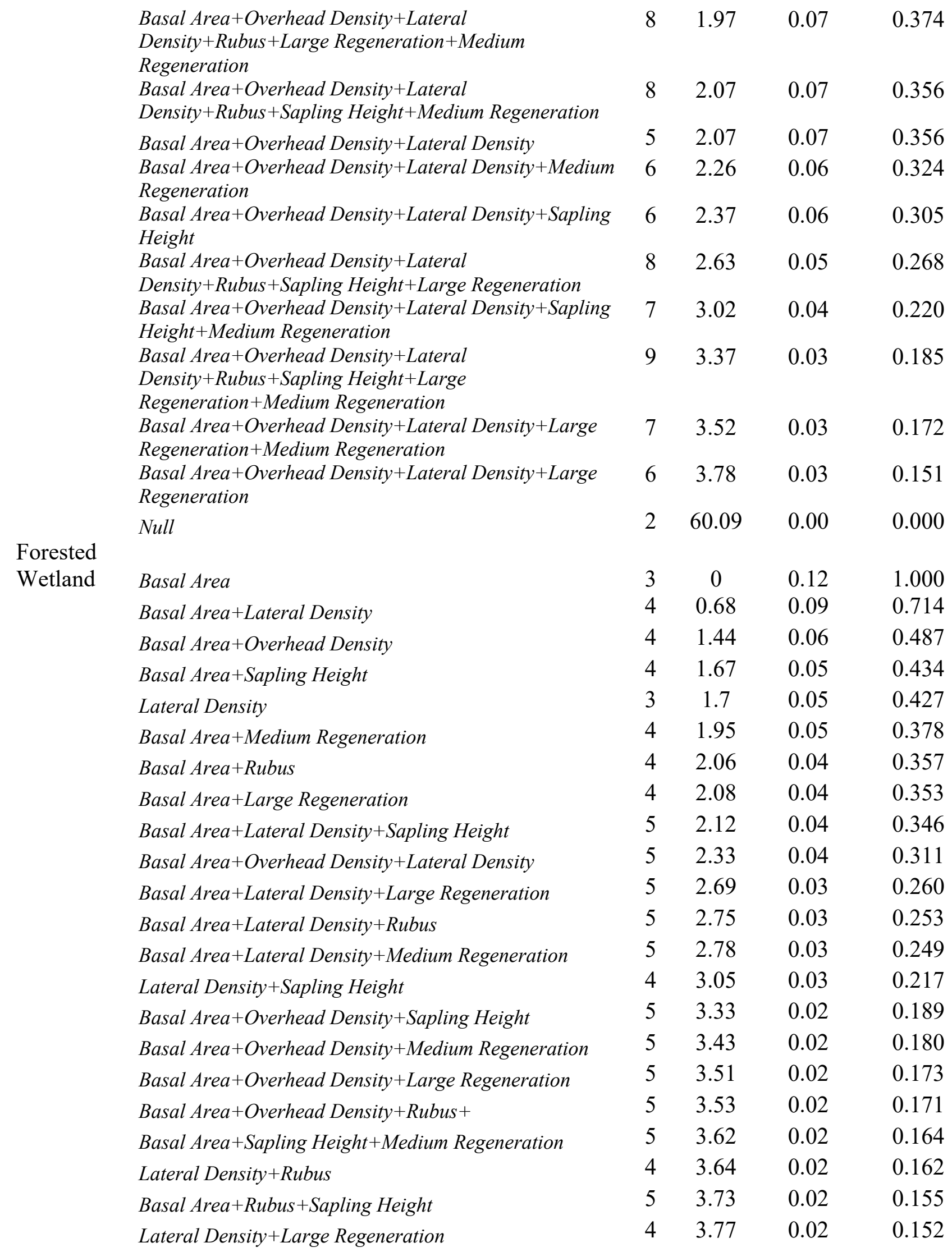




\begin{tabular}{|c|c|c|c|c|}
\hline Basal Area + Sapling Height + Large Regeneration & 5 & 3.77 & 0.02 & 0.152 \\
\hline Overhead Density + Lateral Density & 4 & 3.78 & 0.02 & 0.151 \\
\hline Lateral Density + Medium Regeneration & 4 & 3.79 & 0.02 & 0.151 \\
\hline $\begin{array}{l}\text { Basal Area }+ \text { Overhead Density }+ \text { Lateral Density }+ \text { Sapling } \\
\text { Height }\end{array}$ & 6 & 4.02 & 0.02 & 0.134 \\
\hline Basal Area + Large Regeneration + Medium Regeneration & 5 & 4.03 & 0.02 & 0.133 \\
\hline Basal Area + Rubus + Medium Regeneration & 5 & 4.03 & 0.02 & 0.133 \\
\hline $\begin{array}{l}\text { Basal Area }+ \text { Lateral Density }+ \text { Sapling Height }+ \text { Large } \\
\text { Regeneration }\end{array}$ & 6 & 4.14 & 0.02 & 0.126 \\
\hline Null & & 7.14 & 0.00 & 0.028 \\
\hline Basal Area + Overhead Density + Herbaceous & 5 & 0 & 0.17 & 1.000 \\
\hline $\begin{array}{l}\text { Basal Area }+ \text { Overhead Density }+ \text { Lateral } \\
\text { Density }+ \text { Herbaceous }\end{array}$ & 6 & 0.12 & 0.16 & 0.944 \\
\hline $\begin{array}{l}\text { Basal Area }+ \text { Overhead Density }+ \text { Sapling } \\
\text { Height }+ \text { Herbaceous }\end{array}$ & 6 & 1.41 & 0.08 & 0.494 \\
\hline Basal Area + Overhead Density + Rubus + Herbaceous & 6 & 1.41 & 0.08 & 0.494 \\
\hline $\begin{array}{l}\text { Basal Area }+ \text { Overhead Density }+ \text { Lateral Density }+ \text { Sapling } \\
\text { Height }+ \text { Herbaceous }\end{array}$ & 7 & 1.58 & 0.08 & 0.455 \\
\hline $\begin{array}{l}\text { Basal Area }+ \text { Overhead Density }+ \text { Lateral } \\
\text { Density }+ \text { Rubus }+ \text { Herbaceous }\end{array}$ & 7 & 1.71 & 0.07 & 0.425 \\
\hline Overhead Density + Lateral Density + Herbaceous & 5 & 1.75 & 0.07 & 0.417 \\
\hline $\begin{array}{l}\text { Overhead Density }+ \text { Lateral Density }+ \text { Sapling } \\
\text { Height }+ \text { Herbaceous }\end{array}$ & 6 & 2.61 & 0.05 & 0.272 \\
\hline Overhead Density + Lateral Density + Rubus + Herbaceous & 6 & 2.69 & 0.04 & 0.260 \\
\hline Overhead Density + Herbaceous & 4 & 2.92 & 0.04 & 0.232 \\
\hline $\begin{array}{l}\text { Basal Area }+ \text { Overhead Density }+ \text { Rubus }+ \text { Sapling } \\
\text { Height }+ \text { Herbaceous }\end{array}$ & 7 & 3.05 & 0.04 & 0.217 \\
\hline Overhead Density + Rubus + Herbaceous & 5 & 3.31 & 0.03 & 0.191 \\
\hline $\begin{array}{l}\text { Basal Area }+ \text { Overhead Density }+ \text { Lateral } \\
\text { Density }+ \text { Rubus }+ \text { Sapling Height }+ \text { Herbaceous }\end{array}$ & 8 & 3.34 & 0.03 & 0.189 \\
\hline Overhead Density + Sapling Height + Herbaceous + & 5 & 3.52 & 0.03 & 0.172 \\
\hline $\begin{array}{l}\text { Overhead Density }+ \text { Lateral Density }+ \text { Rubus }+ \text { Sapling } \\
\text { Height }+ \text { Herbaceous }\end{array}$ & 7 & 3.96 & 0.02 & 0.138 \\
\hline Null & 2 & 55.36 & 0.00 & 0.000 \\
\hline
\end{tabular}

